\title{
Molecular Genetic Strategies in the Study of Corticohippocampal Circuits
}

\author{
Christopher C. Angelakos and Ted Abel \\ Department of Biology, University of Pennsylvania, Philadelphia, Pennsylvania 19104-6018 \\ Correspondence: abele@sas.upenn.edu
}

The first reproductively viable genetically modified mice were created in 1982 by Richard Palmiter and Ralph Brinster (Palmiter RD, Brinster RL, Hammer RE, Trumbauer ME, Rosenfeld MG, Birnberg NC, Evans RM. 1982. Dramatic growth of mice that develop from eggs microinjected with metallothionein-growth hormone fusion genes. Nature 300: 611-615). In the subsequent 30 plus years, numerous ground-breaking technical advancements in genetic manipulation have paved the way for improved spatially and temporally targeted research. Molecular genetic studies have been especially useful for probing the molecules and circuits underlying how organisms learn and remember-one of the most interesting and intensively investigated questions in neuroscience research. Here, we discuss selected genetic tools, focusing on corticohippocampal circuits and their implications for understanding learning and memory.

G enetic approaches can be subdivided into two main categories-forward genetic and reverse genetic dissection. Forward genetic analysis involves observing a phenotype, and then identifying the responsible gene(s). This approach has been especially successful in Drosophila research, leading to the discovery of genes important for memory encoding, such as dunce and rutabaga (Dudai et al. 1976; Livingstone et al. 1984). However, forward genetic dissection has been difficult to implement in rodent research owing to the complexity of rodent behaviors (Takahashi et al. 2008).

In contrast, reverse genetic analysis-manipulating gene(s) and observing phenotype-has been immensely successful for studying learning and memory in mice, the closest phylogenetic relative to humans on which pow- erful genetic manipulation can be conferred. A series of studies by Martin Evans, Mario Capecchi, and Oliver Smithies in the 1980s led to the development of the first "knockout" mouse in 1989 (Evans and Kaufman 1981; Bradley et al. 1984; Smithies et al. 1985; Doetschman et al. 1987; Thomas and Capecchi 1987; Mansour et al. 1988). Knockout mice have a gene deleted by injecting a nonfunctional homolog of the gene into mouse embryonic stem cells. The inactivated gene then replaces the endogenous gene through homologous recombination. These stem cells are then implanted into the embryo of another mouse strain, and the resulting offspring, lacking the targeted gene, are selected and bred. For example, knocking out $\alpha$-calcium-calmodulin-dependent protein kinase II $(\alpha$-CaMKII), a protein preferentially

Editors: Eric R. Kandel, Yadin Dudai, and Mark R. Mayford

Additional Perspectives on Learning and Memory available at www.cshperspectives.org

Copyright (C) 2015 Cold Spring Harbor Laboratory Press; all rights reserved; doi: 10.1101/cshperspect.a021725

Cite this article as Cold Spring Harb Perspect Biol 2015;7:a021725 
expressed in excitatory forebrain neurons, results in deficits in spatial memory and longterm potentiation (LTP), the presumptive cellular correlate of learning (Silva et al. 1992a,b). Knockout technologies have also been used to show the importance of posttranslational DNA modifications for learning and memory. For example, knocking out Gadd45b, a gene involved in activity-induced DNA methylation, results in abnormal dendritic development of newborn neurons in the adult brain, deficient long-term contextual fear memory, and the reduction of genes necessary for adult neurogenesis (Ma et al. 2009; Leach et al. 2012). Moreover, knockout of the cyclic adenosine monophosphate (cAMP) response element-binding (CREB) protein (CBP), which can act as a histone acetyltransferase, impairs long-term fear and object-recognition memory and well as LTP (Alarcón et al. 2004). Conversely, knocking out histone deacetylase 2 (HDAC2), an enzyme that removes posttranslational amino-terminal acetyl residues on histones, increases fear memory and LTP (Guan et al. 2009).

In contrast to knockout mice, transgenic (random integration) and knockin (targeted insertion) mice have a gene added into their genome rather than deleted. Knockin technology may be used to render an endogenous gene inactive by introducing a nonfunctional variant of the gene, such as one containing a point mutation in the functional domain. In contrast to knockouts, the knockin approach spares other domains of the protein, such as regulatory regions, and may assuage some of the difficulties in interpreting complex phenotypes resulting from knocking out a gene of interest. For example, knockin techniques revealed that the functional domain of the transcriptional coactivator CBP is necessary for long-term memory storage (Wood et al. 2005, 2006).

Although knockout and knockin techniques are reproducible and may serve as a good model of human genetic disorders, they suffer from many disadvantages. Namely, the earliest versions of these methodologies had no spatial or temporal sensitivity. A gene may have differential functions between development and adulthood, and deleting a gene may result in nonphysiological compensatory mechanisms during development. The NR1 subunit of the $N$-methyl-D-aspartate (NMDA) receptor is important for spatial memory (Tsien et al. 1996b). However, these findings would not have been possible without spatially restricted genetic deletion, as NR1 knockout animals die neonatally (Forrest et al. 1994). Additionally, mice having a dominant-negative form of CREB show dwarfism and hypoplasia in the anterior pituitary (Struthers et al. 1991), whereas targeted deletion of the $\alpha$ and $\delta$ isoforms of CREB show deficits in long-term, but not short-term memory (Bourtchuladze et al. 1994). The differences in these phenotypes can be explained by strong up-regulation and compensation by $\beta$ CREB, which is normally found in very low levels and is likely to have a relatively minor role in wild-type (WT) animals (Blendy et al. 1996; Gass et al. 1998).

These findings clearly show the limitations of conventional knockout, knockin, and transgenic genetic manipulation. To circumvent these issues, more spatially and temporally restricted genetic technologies had to be developed. Here, we will discuss some of the major recent technical advancements in the field of molecular genetics, including the discovery of spatially restricted promoters, as well as the advent of viral, pharmacological, and optical manipulations. In the context of these approaches, we will highlight evidence for the importance of corticohippocampal circuitry for various forms of learning and memory.

\section{SPATIALLY RESTRICTED PROMOTERS}

The targeting of proteins expressed selectively in certain cell types or brain regions has allowed for more spatially restricted genetic manipulation. By driving expression of a transgene using one (or more) of these promoters, one can probe the functional significance of specific brain regions or even cell types without harsh, nonselective lesions or pharmacological inactivation. Numerous brain region-specific promoters exist, including a minimal Msx 1 promoter for craniofacial tissues (Takahashi et al. 1997), Drd1a for striatonigral neurons and Drd2 for striato- 
pallidal neurons (Gerfen et al. 1990), and Etv1 for layer 5 of the neocortex, the main output layer of the cortex (Yoneshima et al. 2006). Examples of cell-type-specific promoters include the neuron-specific endolase (NSE) (Forss-Petter et al. 1990), the astrocyte-specific glial fibrillary acidic protein (GFAP) (Brenner et al. 1994), and the Purkinje cell and retinal bipolar neuron-specific L7/Pcp2 (Oberdick et al. 1990).

One especially useful brain region-specific promoter for the field of learning and memory is the $\alpha$-CaMKII promoter, which is preferentially expressed in adult forebrain neurons, including throughout the hippocampus (Mayford et al. 1996a). $\alpha$-CaMKII protein is not only spatially restricted to brain regions known to be important for learning and memory, but it is also temporally restricted in that its expression levels are 20- to 60-fold higher at 3-4 wk postnatal than during development (Sugiura and Yamauchi 1992). This temporal window allows researchers to probe learning and memory, specifically during time points when synaptic connections underlying higher order cognitive functions are strengthening, while also avoiding many of the aforementioned developmental issues of genetic manipulation. Under control of the $\alpha$-CaMKII promoter, researchers have manipulated and investigated molecules important for learning and memory, such as the regulatory subunit of protein kinase A (PKA) (Abel et al. 1997), brain-derived neurotrophic factor (BDNF) (Cunha et al. 2009), and cyclin-dependent kinase 5 (Cdk5) (Su et al. 2013). Additionally, researchers have used the $\alpha$-CaMKII promoter in concert with other genetic tools, such as Cre recombinase (Tsien et al. 1996a), the tetracycline transactivator system (tTA) (Mayford et al. 1996b), and pharmacogenetic manipulation (Cao et al. 2008), to probe memory function. These techniques will be discussed in detail below.

\section{DOMINANT-NEGATIVE INHIBITION}

First suggested as a research tool by Hershkowitz in 1987, dominant-negative mutations involve using a mutated, nonfunctional variant of a protein of interest to probe the protein's func- tion (Hershkowitz 1987). Because the mutation is "dominant," this manipulation overrides the endogenous version of the protein. Examples of dominant-negative mutation strategies include mutating the catalytic subunit of an enzyme while leaving the localization sequence intact, or mutating a protein that must combine into a multimer to function. Dominant-negative inhibition is especially useful for situations in which different molecules can activate the same signaling pathway, or when different isoforms of a protein exist. Where deleting a gene using conventional knockout strategies might allow for compensatory mechanisms, dominant-negative inhibition may still render the protein or pathway inactive.

In 1997, Abel and colleagues in the Kandel laboratory used dominant-negative techniques to generate a catalytically inactive form of the regulatory subunit of $\mathrm{PKA}$, known as $\mathrm{R}(\mathrm{AB})$ (Abel et al. 1997). PKA is cAMP dependent, but has two cAMP-binding sites. Previous studies knocking out each of the individual cAMP subunits $\left(\mathrm{RI} \beta\right.$ and $\left.C \beta_{1}\right)$ failed to alter the activity of PKA, likely because of compensation by the other cAMP subunit (Brandon et al. 1995; Qi et al. 1996). However, the dominant-negative mutation was able to render both subunits inactive simultaneously. $\mathrm{R}(\mathrm{AB})$ mice showed deficient long-term contextual fear memory, decreased late phase LTP (L-LTP), and impaired spatial memory on a Morris water maze probe trial task. However, short-term contextual fear memory and early phase LTP (E-LTP) were normal in these animals (Abel et al. 1997). Collectively, these experiments revealed the necessity of PKA for consolidation of short-term memory into protein synthesis-dependent long-term memory.

More recently, dominant-negative transgenic mice driven by the $\alpha$-CaMKII promoter have been used to show the importance of proteins involved in transcription for the formation of long-term memories. The transcriptional coactivators CBP and p300, for example, interact with histone acetyltransferases (HATs) and numerous transcription factors known to be important for long-term memory formation (Vo and Goodman 2001). Mice expressing domi- 
nant-negative CBP in $\alpha$-CaMKII ${ }^{+}$cells show impairments in a long-term visual-paired comparison task, the Morris water maze, and latephase LTP (Korzus et al. 2004; Wood et al. 2005). Meanwhile, mice expressing dominantnegative p300 show deficits in long-term contextual fear and object-recognition memory (Oliveira et al. 2007). Additionally, mice expressing a dominant-negative $\mathrm{Ca}^{2+} /$ calmodulin selectively in excitatory forebrain nuclei have decreased gene expression and deficient longterm contextual fear memory, novel object recognition, and Morris water maze performance (Limbäck-Stokin et al. 2004).

\section{Cre/IoxP SYSTEM}

The Cre/loxP system is used, naturally, by the P1 bacteriophage to circularize DNA and aid in the replication process. In 1988, this system was engineered into mammalian cells by Sauer and Henderson (1988), allowing for cell-type or sitespecific deletion of a single mammalian gene. LoxP sites can be inserted into embryonic stem cells via homologous recombination such that two loxP sites "flank" one or more exons encoding a targeted gene. Crossing a flanked mouse line with a mouse line expressing Cre recombinase under control by a cell-type or site-specific promoter deletes the targeted gene wherever the promoter being used to drive Cre recombinase is expressed. Because of disparate sites of Cre transgene integration into the genome, different Cre mouse lines created under control of the same promoter will have slightly different Cre expression patterns. This characteristic of Cre recombination has allowed the Tonegawa laboratory to create mouse lines with specific deletions in the CA1, CA3, or dentate gyrus (DG) subregions of the hippocampus proper (Fig. 1). For example, driving Cre recombinase expression with the $\alpha$-CaMKII promoter produced several founder lines of transgenic mice with varied patterns of Cre expression. Surprisingly, one founder line showed expression of Cre recombinase seemingly selective for area CA1 of the hippocampus, allowing for hippocampus subregion-specific genetic manipulation for the first time (Tsien et al. 1996a).
Because NMDA receptors (NMDARs) were known to be crucial for LTP in the hippocampus (Bliss and Collingridge 1993), the Tonegawa laboratory decided to use this mouse line to selectively delete the NMDA receptor 1 gene, which encodes the NR1 subunit of NMDARs, from CA1 pyramidal cells. These mice did not show LTP in CA1 and showed impaired spatial memory, whereas nonspatial forms of memory remained intact (Fig. 1C-E) (Tsien et al. 1996b). CA1 pyramidal cells, called "place cells," are known to preferentially fire when an animal is in a certain location in space (O'Keefe and Dostrovsky 1971; see Moser et al. 2015), leading to the theory that these cells encode spatial information by making up an internalized geographical representation of an animal's environment. Using the same CA1 NMDAR1 deleted mouse line, Wilson's laboratory showed that the spatial specificity of the firing patterns of individual CA1 place cells was significantly decreased, further corroborating the importance of region CA1 for representing spatial memory (McHugh et al. 1996). However, more recent studies in a mouse line using a genetic silencer to conditionally delete NMDARs in adult CA1 neurons reveal normal acquisition and storage of spatial memory (Bannerman et al. 2012). This and other evidence suggests that the spatial memory deficits seen using the purported CA1specific Cre founder line may in part be caused by spread of Cre expression (and, thus, NMDAR deletion) to overlying cortical neurons (see Hoeffer et al. 2008; Wiltgen et al. 2010).

Using the same principles of differential Cre expression among founder lines, the Tonegawa laboratory then drove Cre recombinase with the kainite KA1 promoter, which is preferentially expressed in hippocampus regions CA3 and DG (Wisden and Seeburg 1993). One founder line possessed CA3-specific Cre recombination. Deleting the NR1 subunit of the NMDAR in CA3 produced mice that could acquire and retrieve spatial memories as well as WT animals, but suffered from significant deficits in retrieving these memories if presented with only a subset of the original visual cues (Fig. 1G,H). Moreover, these mice had normal CA1 place fields under full-cue task conditions, but de- 
A

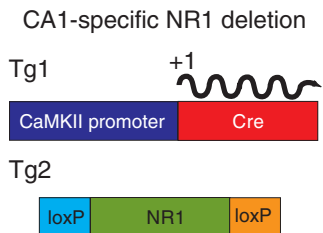

B

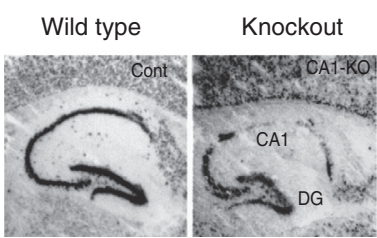

C
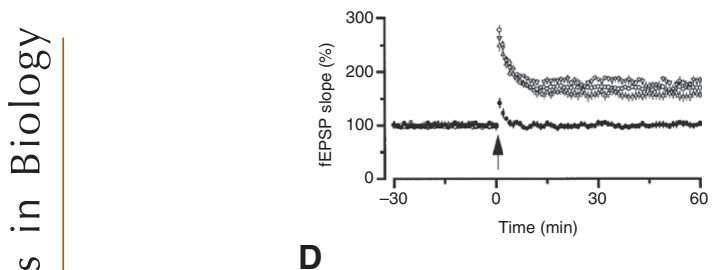

D

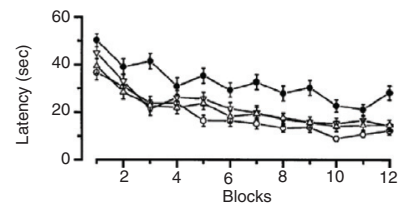

E

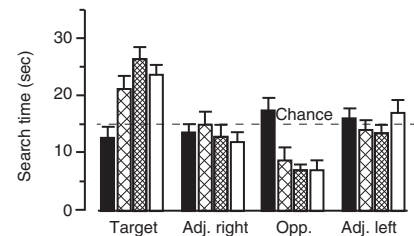

CA3-specific NR1 deletion

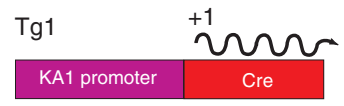

Tg2

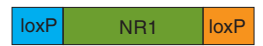

Wild type
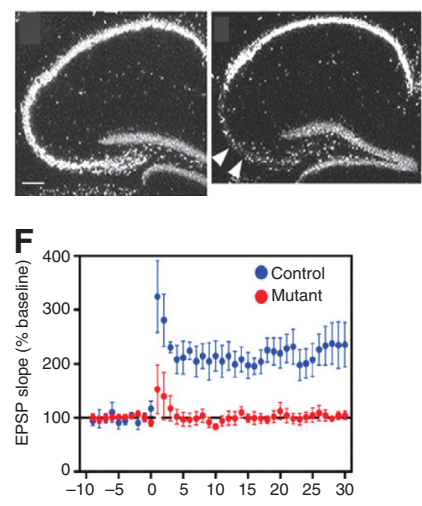

Time (min)

a

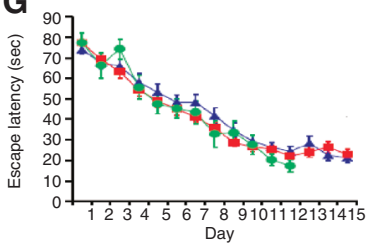

H

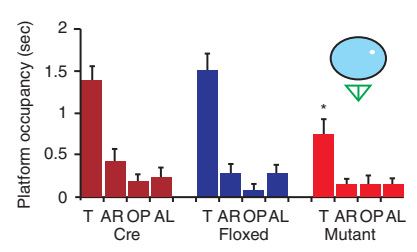

DG-specific NR1 deletion

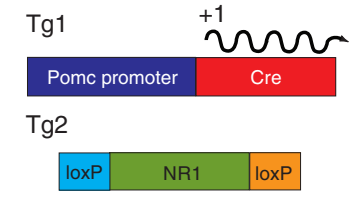

Wild type Knockout

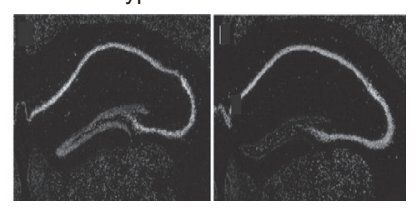

I

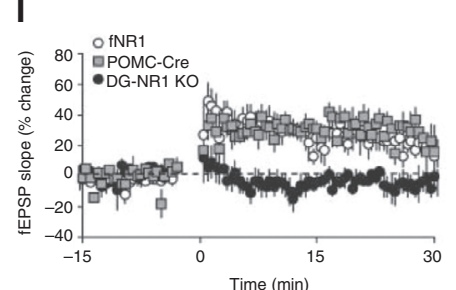

$\mathbf{J}$

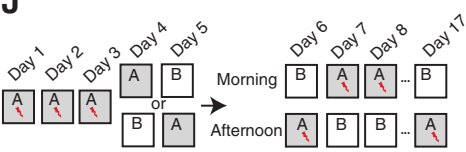

Figure 1. The deletion of $N$-methyl-D-aspartate (NMDA) receptor NR1 subunit in specific subregions of the hippocampus. (A) Loss of NMDA receptor function in specific hippocampal areas can be achieved by using specific promoters to drive Cre recombinase. (B) In situ hybridization of NMDAR1 mRNA from wild types (WTs) (left panels) and subregion-specific NR1 knockout (KO) mice (right panels). (C) CA1-restricted deletion of the NR1 subunit impairs long-term potentiation (LTP) in the Schaffer collateral pathway (open symbols, WTs; closed circles, mutant). (D) CA1-specific knockout mice are impaired during training in the spatial version of the Morris water maze (open symbols, WTs; closed circles, mutant), and (E) during the probe test (black bars indicate mutants). (F) CA3-specific deletion of the NR1 subunit blocks LTP at the recurrent commissural/ associational synapses. $(G)$ CA3-specific knockout does not affect training in the spatial version of the Morris water maze, $(H)$ but results in a reduced preference for the target quadrant during a probe trial with partial cues, indicating an impairment in pattern completion. (I) Perforant path LTP is lost as a consequence of ablation of the NR1 subunit in the dentate gyrus. $(J)$ A design to test context discrimination in WT and dentate gyrusspecific NMDA receptor knockout mice. For the first 3 days of conditioning, mice visited only chamber A and each day received a single foot shock. Freezing was measured once in chamber A and once in chamber B over the subsequent 2 days. During days 6-17, mice visited each chamber daily (receiving a shock in one of the two), and freezing was assessed during the first $3 \mathrm{~min}$ in each chamber. $(K)$ Dentate gyrus (DG)-restricted ablation of NMDA receptors results in impaired pattern separation indicated by a reduced discrimination ratio between a shocked context (context A) and a nonshocked context (context B). adj., Adjacent; opp., opposite. (From Havekes and Abel 2009; reprinted, with permission, from Elsevier (C) 2009; original sources for data are Tsien et al. 1996b; Nakazawa et al. 2002; McHugh et al. 2007.) 
creased place cell specificity under partial-cue conditions (Nakazawa et al. 2002). Thus, in agreement with earlier behavioral work (Moser et al. 2015), region CA3 of the hippocampus seems to play an important role in pattern completion-that is, the ability to retrieve a complete memory from an incomplete set of cues. Subsequent experiments showed that these mice also have impaired one-trial memory on a delayed matching-to-place (DMP) version of the water maze (Steele and Morris 1999), in which the location of the escape platform is altered each day (Nakazawa et al. 2003).

Analogous methods were used to obtain DG-specific Cre recombination. The proopiomelanocortin (PomC) promoter is expressed in the dentate gyrus granule cell layer, arcuate nucleus of the hypothalamus, and the nucleus of the solitary tract (Balthasar et al. 2004). McHugh and colleagues (McHugh et al. 2007) used the PomC promoter in conjunction with the Cre/loxP system to generate a transgenic line with DG-specific NMDAR receptor NR1 deletion. These mice performed normally on a contextual fear-conditioning task, but were impaired at differentiating between two similar contexts (Fig. 1J,K). These findings, along with earlier behavioral work, indicate that the DG is important for pattern separation- the ability to discriminate between similar memories in time and space.

Apart from these examples, Cre/loxP deletion in adult forebrain excitatory neurons using the $\alpha$-CaMKII promoter has revealed the importance of numerous molecules for learning and memory. For example, BDNF and the neural cell-adhesion molecule (NCAM) have both been shown to be important for LTP in region CA1 of the hippocampus (Xu et al. 2000; Bukalo et al. 2004). Using this methodology, the Abel laboratory deleted the transcriptional coactivator p300 from the adult forebrain, establishing its importance for long-term novel object recognition and long-term contextual fear memory (Oliveira et al. 2011).

The Cre/loxP system has allowed for precise cell-type or brain region-specific genetic manipulation. Despite this advantage, Cre recombination does not allow for temporal ma- nipulation apart from using promoters that are expressed selectively at different times of development. Our memories have both spatial and temporal components. Without being able to genetically assess the temporal dynamics of memory, we cannot efficiently proceed to address some of the fundamental questions of the molecules and circuitry underlying learning and memory. Thus, development of a technology allowing for inducible genetic manipulation was needed to probe these questions. The tTA allows researchers to do just that.

\section{TETRACYCLINE TRANSACTIVATOR SYSTEM}

The Tn10-specified tetracycline-resistance operon of Escherichia coli was genetically modified in 1992 by Gossen and Bujard (1992) to temporally control gene expression in the HeLa cell line. In E. coli, the tetracycline repressor protein (tetR) binds to its operator, which suppresses the expression of resistance genes. In the presence of the antibiotic tetracycline, tetR dissociates from its operator, allowing for the expression of resistance proteins and antibiotic resistance. Gossen and Bujard fused the tetR protein with the activation domain of the herpes simplex virus, creating a version of tet $R$ called tTA that was functional in eukaryotic cells. When tTA binds to the tetracycline operator (tetO), the transcription of a transgene of interest takes place. In the presence of tetracycline or doxycycline (Dox), which can be administered through a mouse's food or water, the tetracycline system is suppressed, allowing for temporal control of transgene expression.

In 1996, Mark Mayford in the Kandel laboratory used the tTA system to reversibly express a $\mathrm{Ca}^{2+}$-independent, constitutively active CaMKII in a forebrain-specific manner (Mayford et al. 1996b). This was achieved by crossing mice expressing tTA under control of the $\alpha$-CaMKII promoter with mice expressing a dominant active $\alpha$-CaMKII (CaMKII-Asp ${ }^{286}$ ) driven by the tetO promoter (Fig. 2). The bitransgenic offspring showed deficits in spatial memory, and LTP in the $\theta$ frequency range $(10 \mathrm{~Hz})$ was eliminated in CA1 of the hippocampus. Interesting- 
A

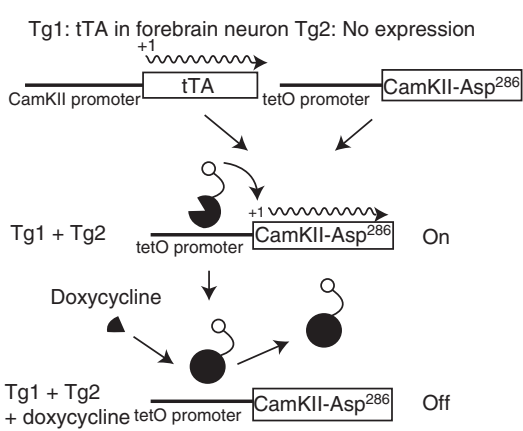

C

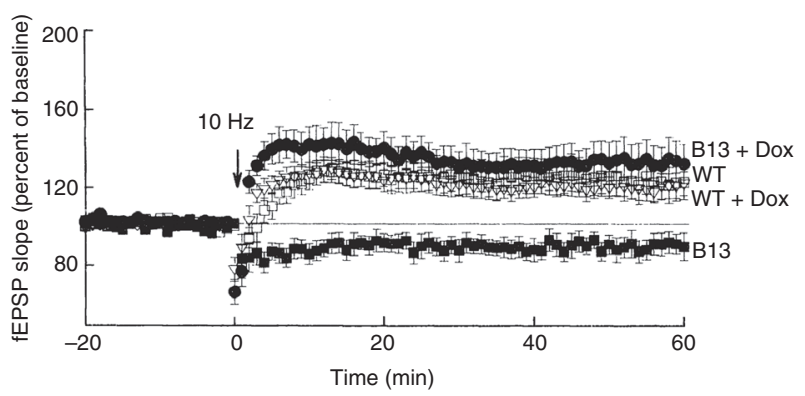

D

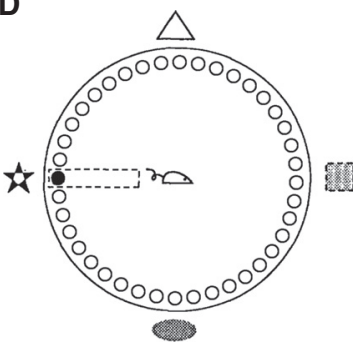

$\mathbf{E}$

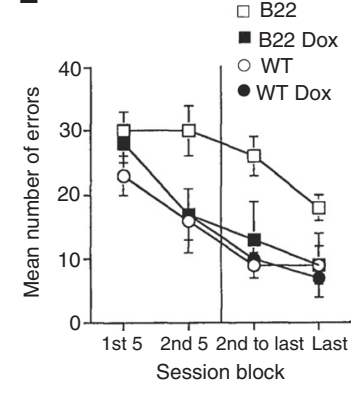

Figure 2. Regulation of the $\alpha$-calcium-calmodulin-dependent protein kinase II (CaMKII) transgene with the tetracycline transactivator (tTA) system reversibly alters long-term potentiation (LTP) and spatial memory. $(A)$ Strategy used to obtain forebrain-specific doxycycline (Dox)-regulated transgene expression. Two independent lines of transgenic mice are obtained, and the two transgenes are introduced into a single mouse through mating. (B) Quantification by RT-PCR Southern blot of CaMKII-Asp ${ }^{286}$ expression from the tetO promoter (Tg1, mouse carrying only the CaMKII promoter-tTA transgene; Tg2, mouse carrying only the tetO-CaMKII-Asp ${ }^{286}$ trans- $^{-}$ gene; Tgl/Tg2, double transgenic mouse carrying both the CaMKII promoter-tTA transgene and tetO-CaMKII$\mathrm{Asp}^{286}$ transgenes; $\mathrm{Tg} 1 / \mathrm{Tg} 2+$ Dox, double transgenic mouse treated with doxycycline $[2 \mathrm{mg} / \mathrm{ml}]$ plus $5 \%$ sucrose in the drinking water for $4 \mathrm{wk}$ ). (C) Double transgenic mice (B13) fail to potentiate following stimulation at $10 \mathrm{~Hz}$ for $1.5 \mathrm{~min}$. Doxycycline treatment reversed the defect in B13 mice. $(D)$ The Barnes circular maze. In this spatial memory task, mice are required to use distal cues to find the location of the escape hole. (E) Mean number of errors across session blocks composed of five sessions. Double transgenic mice (B22) show impaired performance on the Barnes maze. This impairment is reversed after doxycycline treatment. WT, Wild type. (From Mayford et al. 1996b; reprinted, with permission, from The American Association for the Advancement of Science (C) 1996.)

ly, when the transgenic CaMKII-Asp ${ }^{286}$ was suppressed by administering Dox through the drinking water, the memory and LTP impairments were restored to normal (Fig. 2C-E) (Mayford et al. 1996b). This seminal study showed unequivocally that these memory deficits were exclusively caused by adult neuronal activity, separate of any developmental effects.

One advantage of the tTA system over previously available genetic strategies is its ability to dissociate different stages of memory temporally for the first time. For example, Isiegas and colleagues (Isiegas et al. 2006) used the tetracy- cline system to temporally control dominantnegative $R(A B)$ expression in adult forebrain neurons. By keeping mice on Dox during development and contextual fear conditioning, Isiegas et al. were then able to elucidate the role of PKA selectively in fear extinction by removing Dox before initiating a fear extinction paradigm. They found that inhibition of PKA facilitates fear extinction, suggesting that PKA may help protect against memory erasure.

The temporal-resolution advantages of the tetracycline system are best revealed when combined with other spatially specific genetic ma- 
nipulations, such as the aforementioned hippocampus subregion-specific knockouts. By combining the tTA system with the predominantly CA1 Cre/loxP deletion of the NR1 subunit of the NMDA receptor, Shimizu et al. (Shimizu et al. 2000) assessed the role of the NMDAR on long-term memory consolidation. Here, a Dox-on system was used such that administration of Dox knocked out NMDARs in CA1, whereas mice off Dox expressed normal NMDAR function. Mice off Dox learned a 7 day Morris water maze hidden-platform task as well as control animals. However, when Dox was administered after training (during consolidation) to knock out CA1-NMDARs, the mutant mice showed memory deficits on a retrieval probe trial, as assessed by increased latency to locate the hidden platform. Analogous results were found when removing NMDARs in CA1 during consolidation of long-term contextual fear memory. These results showed that NMDARs in CA1 are important for the consolidation of short-term hippocampus-dependent memories into long-term memories.

Recently, the Tonegawa laboratory used the tTA system in combination with the Cre/loxP system to temporally restrict synaptic transmission selectively in region CA3 of the hippocampus. The tetanus toxin (TeTX) light chain specifically cleaves synaptobrevin 2, which is part of the vesicle-associated membrane protein (VAMP) family necessary for vesicle release and synaptic transmission. By driving TeTX specifically to CA3 of the hippocampus using the kainate KA1 promoter, the Tonegawa laboratory was able to block synaptic transmission from CA3 to CA1. Controlling this manipulation with the tTA system, they found that CA3TeTX mice had memory impairments in onetrial novel contextual fear conditioning and deficient spatial tuning of CA1 place cells. Incremental spatial memory acquisition and recall in the Morris water maze was normal. Additionally, these mice had memory impairments in a contextual fear paradigm testing pattern-completion-based recall in which mice are first preexposed to the context without footshock before the training day. If administered Dox to repress the TeTX transgene, the CA3-TeTX mice performed similarly to controls, demonstrating in a reversible manner the importance for CA3 $\rightarrow$ CA1 synapses for one-trial memory, spatial representation, and pattern completion (Nakashiba et al. 2008). Subsequent analysis of this mouse line revealed the importance of CA3 output for consolidation of long-term contextual fear memories. Using Dox regulation of transgene expression to block CA3 synaptic transmission during the consolidation phase of memory, contextual fear memory was impaired 6 wk later. However, when CA3 output was normal during consolidation but blocked during retrieval, the mice showed no memory deficits, suggesting that CA3 $\rightarrow$ CA1 synaptic activity is important for the consolidation, but not for the retrieval of long-term contextual memories (Nakashiba et al. 2009).

Next, the Tonegawa laboratory used the same principles to generate DG-TeTX mice under control of the tTA system. The DG of the hippocampus is one of two areas of the brain (along with the subventricular zone) known to generate new neurons into adulthood, a process known as adult neurogenesis (Altman and Das 1965; Eriksson et al. 1998). Using the tTA system, the Tonegawa laboratory was able to block DG $\rightarrow$ CA3 synaptic transmission selectively in developmentally derived DG neurons, while sparing adult-born DG neurons. This manipulation produced normal pattern separation as probed by contextual fear discrimination between disparate contexts, but reduced pattern completion on the preexposure-dependent contextual fear-conditioning paradigm. When young, adult-born DG cells were specifically ablated using X-ray radiation, the mice had deficits in pattern separation of dissimilar contexts. Thus, adult-born DG neurons appear to be necessary for pattern completion, whereas older, developmentally derived DG neurons appear necessary for normal pattern separation (Nakashiba et al. 2012).

Moving out of the hippocampus, the oxidation resistance 1 (oxr1) promoter was recently used to generate a mouse line expressing Cre recombination selectively in superficial layer III of the medial entorhinal cortex (MEC). The MEC has two disparate projections into 
the hippocampus. One, known as the trisysnaptic pathway, originates from layer II of the MEC and projects to the DG and then ultimately to CA3 and CA1. The other, the monosynaptic pathway, projects from layer III of the MEC directly to CA1. Using the tTA system, a pOxr1Cre line, and TeTX driven by the $\alpha$-CaMKII promoter, the Tonegawa laboratory was able to selectively and reversibly block synaptic transmission of the monosynaptic pathway. Doing so produced spatial working memory deficits in the DMP Morris water maze task as well as a delayed nonmatching-to-place Tmaze task. The mutants were also impaired in the acquisition, but not the retrieval phase of cued trace fear conditioning in which a tone was paired temporally with a footshock. Together, these studies suggest that the monosynaptic pathway from MEC layer III $\rightarrow$ CA1 is important for temporal associations and spatial working memory (Suh et al. 2011).

The tTA system has also been used to assess the effects of glia cells on learning and memory. In the 1990s, it was discovered that activation of astrocytic glutamate receptors (GluRs) increases $\mathrm{Ca}^{2+}$ levels in astrocytes, producing astrocytic transmitter release, called "gliotransmission" (Cornell-Bell et al. 1990; Araque et al. 1998). In 2005, Phil Haydon's laboratory generated a mouse line expressing dominant-negative $\mathrm{N}$ ethylmaleimide-sensitive factor attachment protein receptor (dn-SNARE) selectively in astrocytes under temporal control of the tTA system, allowing for attenuation of gliotransmission via disruption of the vesicular release machinery. Using this model, it was discovered that gliotransmission alters both basal neuronal synaptic transmission and late-phase LTP (Pascual et al. 2005). Later studies with dn-SNARE mice showed that these mice are protected against the intense sleep drive and hippocampus-dependent object-recognition memory impairments normally observed following sleep deprivation (Halassa et al. 2009; Florian et al. 2011).

\section{PHARMACOGENETICS}

Although the tTA system allows for inducible and reversible genetic manipulation, the time course of transgene expression/suppression after Dox administration/removal is slow, taking 3-4 wk (Mayford et al. 1996b). One method developed to improve on this issue was made by engineering an inducible form of Cre recombinase and fusing it to a mutated human estrogen receptor (ER) (Metzger et al. 1995). The ER is naturally localized to the cytoplasm by chaperone proteins. Injecting tamoxifen disrupts the interaction between the fusion protein (CreERT2) and chaperone proteins and causes the ER to relocate to the nucleus, initiating Cre recombination of the floxed gene.

This technique was used by Imayoshi et al. (2008) to study neurogenesis in the DG. In one mouse line, CreERT2 was driven by the Nestin promoter, which is expressed in immature progenitor cells. In a second mouse line, a fragment of the diphtheria toxin was knocked into a noncoding region of the mature neuron-specific enolase 2. In this second mouse line, a STOP codon was flanked by lox $\mathrm{P}$ sites. Thus, crossing the two lines (coupled with administration of tamoxifin) produced Cre recombination specifically in newly differentiated mature neurons expressing enolase 2. This manipulation allowed for expression of Diphtheria toxin, specifically killing adult-born neurons. Eliminating neurogenesis in the DG resulted in spatial memory deficits on the Morris water maze as well as deficits in hippocampus-dependent contextual fear conditioning.

A complimentary study, using the CreERT2 system to enhance neurogenesis, was performed in the laboratory of René Hen. Here, a mouse line expressing CreERT2 under control of the Nestin promoter was crossed with a mouse line containing a floxed Bax gene in neural stem cells (Sahay et al. 2011). BAX is proapoptotic (Oltval et al. 1993), and tamoxifin-dependent Cre deletion of BAX results in decreased cell death of neural stem cells. This manipulation leads to a threefold increase of adult-born neurons in the dentate gyrus $6 \mathrm{wk}$ after tamoxifin injection. Behaviorally, these mice displayed normal object recognition, spatial memory, and contextual fear conditioning. Interestingly, these mice had enhanced discrimination of two similar contexts during contex- 
tual fear conditioning, lending further credence to the importance of the DG for pattern separation (Sahay et al. 2011).

Although the CreERT2 system allows for more precise temporal genetic control, tamoxifin is an endogenous antagonist of the ER. Thus, tamoxifin administration affects both the engineered CreERT2 receptor and endogenous ERs, confounding phenotypic interpretations. Moreover, larger quantities of tamoxifin and/or CreERT2 expression have been shown to be toxic (Higashi et al. 2009). Recent advancements have used destabilized forms of Cre (Sando et al. 2013) or synthetic G protein-coupled receptors (GPCRs) that are activated exclusively by synthetic ligands. The first attempt at developing a designer receptor exclusively activated by designer drugs (DREADD), was performed by Strader and colleagues in 1991 by developing a mutated form of the $\beta 2$-adrenergic receptor through site-directed mutagenesis that was not responsive to its endogenous ligand (Strader et al. 1991). However, this receptor had low affinity for its synthetic ligand, making it impractical for in vivo usage.

An improvement on this methodology was developed and used by the Abel laboratory to incorporate the Aplysia $\mathrm{G}_{\mathrm{s}}$-coupled octopamine receptor in mouse excitatory forebrain neurons under control of the tTA system (Fig. 3A) (Isiegas et al. 2008). The octopamine receptor is activated by octopamine, which is found predominately in invertebrates but only in trace levels in mammals (Berry et al. 2004). Injection of octopamine produces rapid increases in cAMP. Using this manipulation, the Abel laboratory found that activating cAMP levels with octopamine increases hippocampus LTP and enhances the consolidation of contextual fear memory (Fig. 3B-D) (Isiegas et al. 2008). In a recent follow-up study, targeted delivery and activation of the octopamine receptor exclusively in hippocampus excitatory neurons during sleep deprivation prevented the object location memory impairments typically observed following sleep loss (Havekes et al. 2014). Together, these studies show the importance of cAMP during both wake and sleep for the consolidation of hippocampus-dependent memories.
Recent technical advancements have resulted in the creation of a wealth of new DREADDs capable for use in vivo. For example, a synthetic $\mathrm{G}_{\mathrm{q}}$-coupled human $\mathrm{M}_{3}$ muscarinic DREADD $\left(\mathrm{hM}_{3} \mathrm{D}_{\mathrm{q}}\right)$ was developed to be selectively activated by the pharmacologically inert drug clozapine- $\mathrm{N}$-oxide (CNO) (Alexander et al. 2009). Mayford and colleagues used a promoter for the transcription factor c-fos to drive expression of this receptor, along with the tTA transgene, to activated neurons. Activated neurons were labeled with the $\mathrm{hM}_{3} \mathrm{D}_{\mathrm{q}}$ receptor during exploration of a novel context (context A). Mice were then injected with $\mathrm{CNO}$ and fear conditioned in a second context (context $\mathrm{B}$ ), activating the same population of neurons that were activated in context A. This manipulation resulted in activation of competing neural ensembles, resulting in a hybrid memory between context $\mathrm{A}$ and context B (Garner et al. 2012).

\section{VIRAL/OPTOGENETIC APPROACHES}

Viruses operate by infecting host cells and incorporating their genetic material into the host's genome. By modifying viruses to remove the harmful components that hijack the host's cellular machinery and instead inserting promoters and transgenes of interest, researchers have been able to develop viral vectors that allow for spatially precise genetic control. A viral construct typically includes a cell-type-specific promoter, a transgene of interest, and a marker, such as a fluorescent protein. Injecting the viral vector into the brain allows for cell-type and brain region-specific delivery of the viral genetic material, termed transduction.

The use of viral vectors has proved fruitful for investigating the roles of corticohippocampal circuitry in learning and memory. In one study, the transcription factor myocyte enhancer factor 2 (MEF2), which negatively regulates the formation of dendritic spines (Flavell et al. 2006), was found to be important for the consolidation of contextual fear memory in the anterior cingulate cortex (ACC). MEF2-dependent transcription was increased in layer $2 / 3$ of the ACC at various time points after contextual fear conditioning using a replication-defective 
A
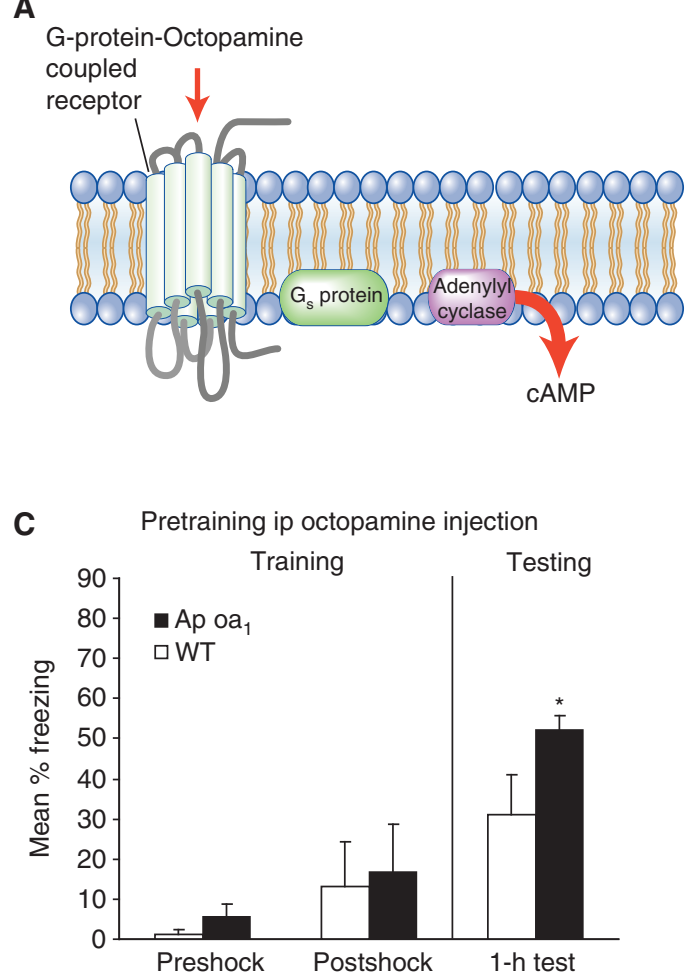

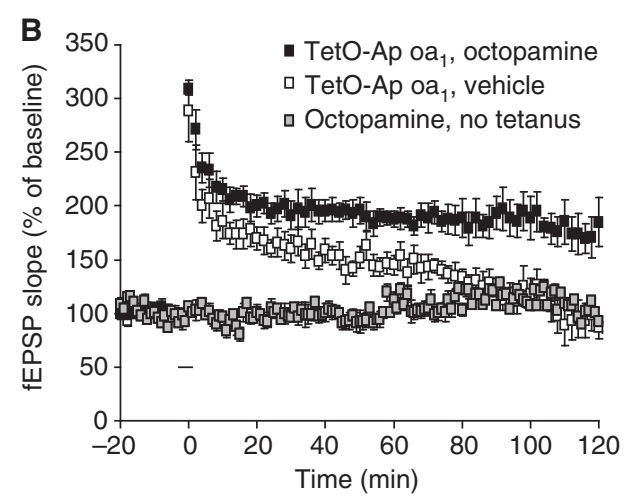

。

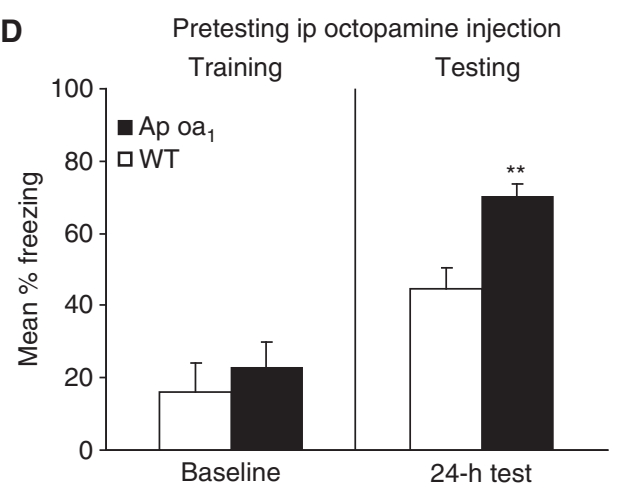

Figure 3. Activation of the octopamine receptor in mouse forebrain neurons enhances long-term potentiation (LTP) and memory. (A) Aplysia octopamine receptor (Ap oa 1 ) is a G-protein-coupled receptor whose activation by octopamine stimulates adenylyl cyclase activity, which in turn synthesizes cyclic adenosine monophosphate (cAMP). (B) Hippocampal one-train LTP $(100 \mathrm{~Hz}$ for $1 \mathrm{sec})$ is potentiated and lengthened in Ap oa ${ }_{1}$ mice after octopamine application. Arrow indicates when the potentiation stimulus was delivered. $(C)$ Training and 24-h long-term memory test during contextual fear conditioning in Ap $\mathrm{oa}_{1}$ transgenic mice and wild-type (WT) littermates injected intraperitoneally with octopamine $30 \mathrm{~min}$ before training. No differences in freezing behavior are observed between Ap oa ${ }_{1}$ transgenic mice and WT littermates before and after the shock during training. In contrast, Ap oa $\mathrm{a}_{1}$ transgenic mice show a significant increase in freezing behavior when reexposed to the fear-conditioned context $24 \mathrm{~h}$ after training. $(D)$ Training and 24-h long-term memory testing during fear conditioning in Ap oa ${ }_{1}$ transgenic mice and WT littermates receiving an intraperitoneal injection of octopamine

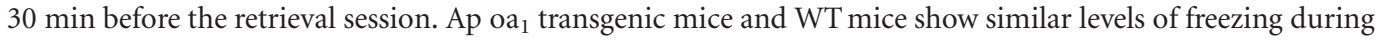
the training session (baseline). However, Ap oa ${ }_{1}$ transgenic mice show significantly increased freezing behavior compared with WT mice during the contextual fear memory test $24 \mathrm{~h}$ after training. (Image reprinted from Isiegas et al. 2008 under the U.S. Fair Use Guidelines available from the Copyright Office at the Library of Congress.)

herpes simplex virus. Mice were injected $1 \mathrm{~d}$ or $42 \mathrm{~d}$ after contextual fear conditioning and memory was tested 1 wk later. Mice with enhanced MEF2-dependent transcription $1 \mathrm{~d}$ after training had decreased fear memory as well as decreased spine density in ACC, whereas mice injected $42 \mathrm{~d}$ after training did not (Vetere et al. 2011). These results suggest that MEF2 acts in a time-dependent manner to negatively regulate memory consolidation and spine formation in layer $2 / 3$ of the ACC. They also show the involvement of the neocortex, in addition to the hippocampus, for the consolidation of contextual fear memories.

A recent study by Lovett-Barron et al. (2014) combined pharmacogenetics, the Cre-LoxP sys- 
tem, and adeno-associated viruses (AAV) to inactivate somatostatin-expressing $\left(\mathrm{SOM}^{+}\right)$interneurons in CA1 and assess their role in two forms of contextual fear conditioning. Neurons expressing the $\mathrm{Cl}^{-}$channel PSAM ${ }^{\mathrm{L} 141 \mathrm{~F}}$ GlyR are inactivated for 15-20 min on administration of the synthetic ligand PSAM $^{89}$. PSAM $^{\mathrm{L} 141 \mathrm{~F}}$-GlyR was packaged in an AAV and injected bilaterally into CA1 of Som-Cre mice. Systemic administration of PSAM $^{89}$ during conditioning impaired memory in both headfixed water-licking suppression contextual fear conditioning (hf-CFC) and freely moving contextual fear conditioning, suggesting that inhibitory circuits comprised of $\mathrm{SOM}^{+}$interneurons in CA1 are necessary for multiple forms of contextual fear conditioning. Inactivating parvalbumin-expressing interneurons in CA1, however, did not impair contextual fear memory. Using a separate AAV to express the $\mathrm{Ca}^{2+}$ indicator GCaMP and two-photon imaging, the researchers also showed that $\mathrm{SOM}^{+}$interneurons in CA1 are preferentially activated during hf-CFC.

As shown in previous studies, the spatial precision of viral techniques is most useful when used in combination with other genetic methodologies. For example, Warburton et al. used an adenovirus to inject a dominant-negative form of CREB (dn-CREB) into the perirhinal cortex. dn-CREB in the perirhinal cortex-impaired long-term object-recognition memory and perirhinal LTP (Warburton et al. 2005). However, perhaps the most fascinating combinatorial approach involves using the spatial precision of viral vectors with the recently developed, temporally precise technique known as optogenetics. Previously mentioned techniques allow for precise genetic manipulation on the course of minutes to hours. However, neurons fire on the order of milliseconds. The development and optimization of optogenetics over the last decade has allowed for millisecond control of neural activity in a brain region or cell-type-specific manner. Optogenetics involves the use of lightactivated ion channels known as opsins, found naturally in certain bacteria or algae, and engineering them into mammalian cells to confer control of neuronal excitability on optical pre- sentation. Channelrhodopsin-2 (ChR2) is one such light-gated proton channel found naturally in the green alga Chlamydomonas reinhardtii. In 2003, Georg Nagel and Ernst Bamberg expressed and characterized ChR2 in Xenopus oocytes and mammalian cell cultures, producing reliable depolarizing currents on activation with 450-nm blue light (Nagel et al. 2003). In 2005, Ed Boyden and Karl Deisseroth collaborated with Nagel and Bamberg and bioengineered ChR2 into cultured mammalian neurons for the first time. They found that ChR2 can produce single neuronal spikes or long trains of depolarization depending on the interval of light stimulation (Boyden et al. 2005).

In recent years, the technique of optogenetics has been applied to the field of learning and memory to study circuitry and populations of cell types with millisecond precision. Pharmacologic and lesion studies indicate that the hippocampus is crucial for recent memories, but, over time, these memories become hippocampus independent, relying instead on the neocortex (i.e., Kim and Fanslow 1992; Maren et al. 1997). To test these ideas with more precise temporal control, Deisseroth's laboratory engineered an enhanced halorhodopsin chloride channel from the archaea Natronomonas pharaoni (eNpHR3.1), which acts as an optogenetic inhibitor on stimulation with $680 \mathrm{~nm}$ red light. CaMKII $\alpha: e N p H R 3.1$ was incorporated into a lentiviral vector and injected into hippocampus CA1 (Fig. 4A,B). Mice were then trained on contextual fear conditioning. Surprisingly, optic inhibition of CA1 during the 5-min test session impaired retrieval of the remote memory $28 \mathrm{~d}$ after training (Fig. 4C). However, if the inhibition interval was prolonged to $30 \mathrm{~min}$, remote memory was undisturbed (Fig. 4D) (Goshen et al. 2011). These findings suggest that the time course of hippocampus inhibition is important-with longer periods of inhibition, as with lesion studies, there may be sufficient time for cortical compensatory circuits to take over. Along these lines, optogenetic inhibition delivered into the anterior cingulate cortex (ACC) impaired remote, but not recent contextual fear memories (Fig. 4E,F) (Goshen et al. 2011). 

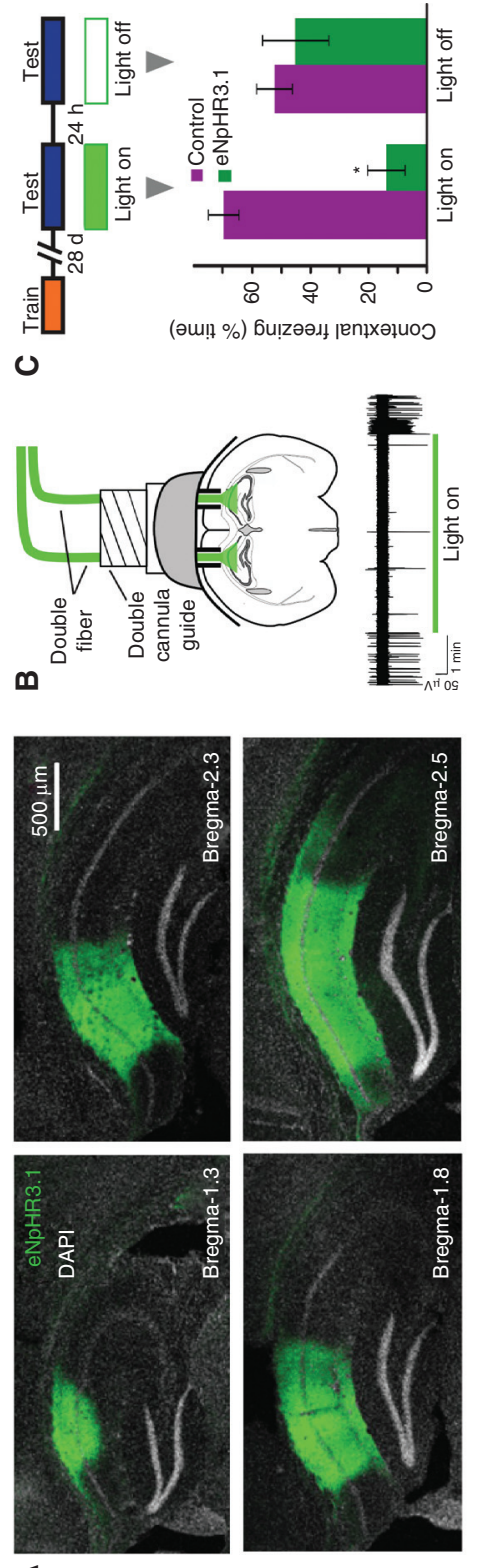

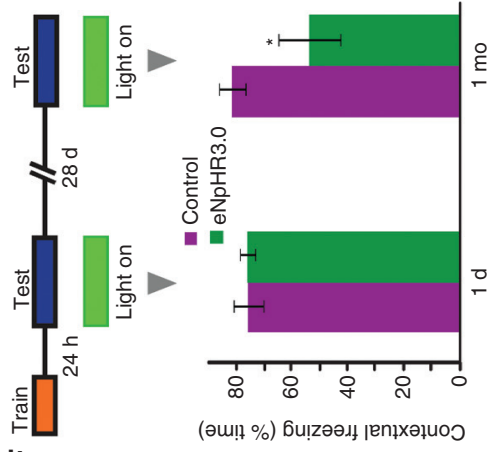

ᄂ

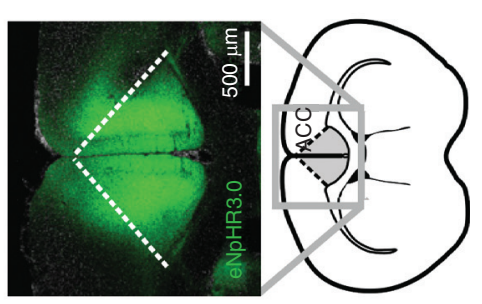

ш

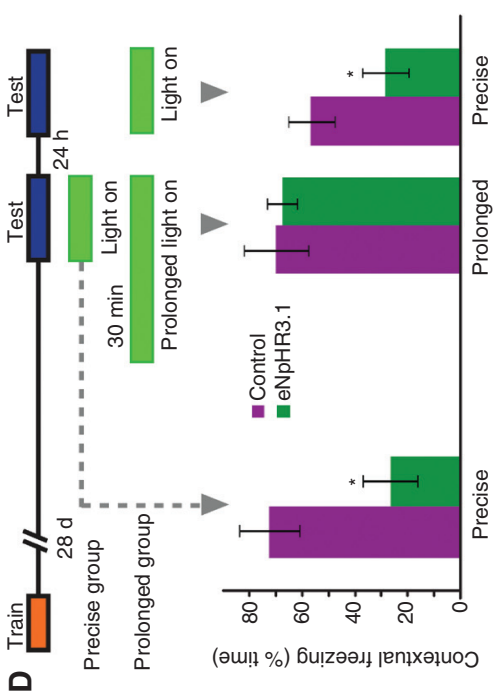

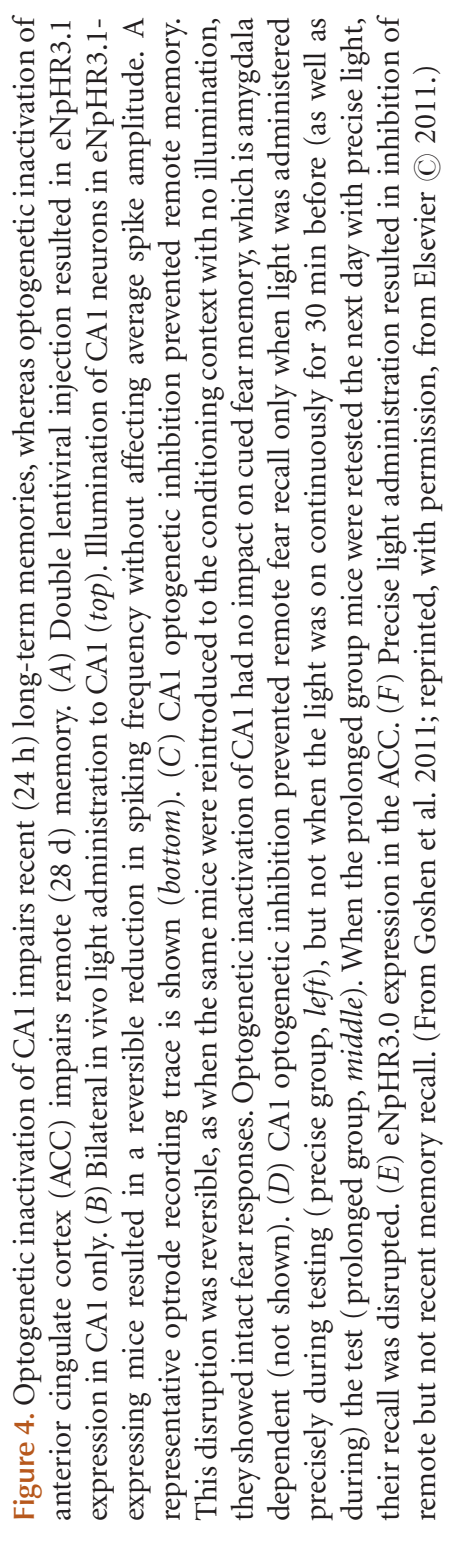


Optogenetic techniques have also been used recently to study the roles of previously difficultto-study regions and cell types of corticohippocampal circuitry. The Tonegawa laboratory used optogenetic stimulation of DG mossy fibers in concert with electrode recording from hippocampus region CA2, an area between CA3 and CA1 comprised of large pyramidal cells, to discover a previously unknown circuit connection from DG $\rightarrow$ CA2. These techniques in combination with CA2-specific markers and tracing studies revealed a trisynaptic circuit from $\mathrm{DG} \rightarrow \mathrm{CA} 2 \rightarrow \mathrm{CA} 1$, the function of which remains to be explored (Kohara et al. 2014). In a separate experiment, the Tonegawa laboratory identified a subset of excitatory cells in entorhinal cortex layer II, which they termed "island cells.” Island cells project to CA1 and inhibit the excitatory projections from medial EC layer III onto CA1 via feedforward inhibition. Island cells are positive for the $\mathrm{Wfs} 1$ promoter and using a Wfs1-Cre line, channelrhodopsin-2 was virally targeted to EC layer II island cells. These island cells were then optically stimulated during trace fear conditioning (TFC), a hippocampus-dependent task in which a delay (trace) is incorporated between the presentation of a tone and a foot shock. Stimulating island cells during TFC resulted in memory impairments both during training and testing. Similar results were observed by optically inhibiting EC layer III inputs to CA1 using the pOxr1-Cre line described earlier. These freezing deficits were not present if the trace interval was removed, suggesting that projections from EC layer II and EC layer III to CA1 are both important for temporal association memory (Kitamura et al. 2014). Optogenetics has also recently been used to label active neurons during contextual fear conditioning by driving expression of ChR2 to DG neurons expressing the $\mathrm{c}$-fos promoter. Mice were placed in a novel context $A$ and active neurons were labeled with ChR2. This population of neurons was then optically activated during fear conditioning in context $\mathrm{B}$. When mice were placed back into context A, they showed enhance freezing even though they were never shocked in context $A$, in effect creating a false memory representation (Ramirez et al. 2013).

\section{CONCLUDING REMARKS}

The use of molecular-genetic techniques to study the corticohippocampal circuitry underlying learning and memory has exploded in the three decades since Palmiter and colleagues developed the first knockout mouse strain (Palmiter et al. 1982). Knockin and dominant-negative approaches have revealed the functionality of disparate subdomains of proteins. The Cre LoxP system, along with the discovery of spatially restricted promoters, have allowed for brain region and cell-type-specific genetic manipulation. The tetracycline system, pharmacogenetics, viral vectors, and optogenetics have made inducible and reversible genetic studies possible (Table 1). When used in combination, these techniques have permitted great spatial and temporal control, leading to some of the fascinating findings reviewed herein.

Still, much improvement in genetic technology is needed. Despite the multitude of genetic tools at researchers' disposal, better spatial and temporal control is needed. One way to improve specificity is through the discovery of new spatially and temporally restricted promoters. For example, no known promoters exist that specifically target the perirhinal cortex, which projects to entorhinal cortex, receives projections from CA1, and plays an important role in memory consolidation (Apergis-Schoute et al. 2007; Furtak et al. 2007). Additionally, promoter expression may change over the course of development, or with neural activity. For instance, the transcription factor zif268 is important for the induction and maintenance of LTP, and is induced in CA1 by contextual fear conditioning and spatial memory (i.e., Cole et al. 1989; Guzowski et al. 2001; Hall et al. 2001; Jones et al. 2001). However, it remains difficult to modulate zif268 with the temporal precision necessary to parse apart its effects on the different stages of memory.

One novel and exciting gene editing technology involves using clustered regularly interspaced short palindromic repeats (CRISPRs) found in bacteria in association with CRISPR associated (cas) genes, such as cas9. The CRISPR/cas9 system delivers cas9 proteins, 
Molecular Strategies for Corticohippocampal Circuits

Table 1. Summary table of genetic techniques outlined in this review and their properties

\begin{tabular}{|c|c|c|c|c|}
\hline $\begin{array}{l}\text { Genetic } \\
\text { technique }\end{array}$ & Regulator & Inducible? & $\begin{array}{l}\text { Promoter- } \\
\text { specific } \\
\text { expression? }\end{array}$ & $\begin{array}{c}\text { Method of } \\
\text { genome insertion }\end{array}$ \\
\hline \multicolumn{5}{|c|}{ Vector delivery techniques } \\
\hline $\begin{array}{l}\text { Conventional } \\
\text { knockout }\end{array}$ & None & No & No & $\begin{array}{l}\text { Targeted mutation through } \\
\text { homologous } \\
\text { recombination }\end{array}$ \\
\hline Knockin & None & $\begin{array}{l}\text { In combination with an } \\
\text { inducible technique }\end{array}$ & Yes & $\begin{array}{l}\text { Targeted mutation through } \\
\text { homologous } \\
\text { recombination }\end{array}$ \\
\hline Transgenesis & None & $\begin{array}{l}\text { In combination with an } \\
\text { inducible technique }\end{array}$ & Yes & $\begin{array}{l}\text { Random insertion into } \\
\text { genome }\end{array}$ \\
\hline Viral vector & None & $\begin{array}{l}\text { In combination with an } \\
\text { inducible technique }\end{array}$ & Yes & $\begin{array}{l}\text { Targeted, random, or } \\
\text { episomal }\end{array}$ \\
\hline \multicolumn{5}{|c|}{ Genetic Manipulation Techniques } \\
\hline $\begin{array}{l}\text { Dominant } \\
\text { negative }\end{array}$ & None & $\begin{array}{l}\text { In combination with an } \\
\text { inducible technique }\end{array}$ & Yes & $\begin{array}{l}\text { Depends on the vector } \\
\text { delivery technique chosen }\end{array}$ \\
\hline Cre/loxP System & Promoter & $\begin{array}{l}\text { Can be (i.e., CreERT2, } \\
\text { DD-Cre) }\end{array}$ & Yes & $\begin{array}{l}\text { Depends on the vector } \\
\text { delivery technique chosen }\end{array}$ \\
\hline $\begin{array}{l}\text { Tetracycline } \\
\text { system }\end{array}$ & Doxycycline & Yes & Yes & $\begin{array}{l}\text { Depends on the vector } \\
\text { delivery technique chosen }\end{array}$ \\
\hline DREADDs & Synthetic ligand & Yes & Yes & $\begin{array}{l}\text { Depends on the vector } \\
\text { delivery technique chosen }\end{array}$ \\
\hline Optogenetics & Light & Yes & Yes & $\begin{array}{l}\text { Depends on the vector } \\
\text { delivery technique chosen }\end{array}$ \\
\hline CRISPR/CAS9 & $\begin{array}{l}\text { Cas9 endonuclease + } \\
\text { guide RNAs }\end{array}$ & Yes & Yes & $\begin{array}{l}\text { Depends on the vector } \\
\text { delivery technique chosen }\end{array}$ \\
\hline
\end{tabular}

along with a guide RNA, to any predetermined location in the genome. This system cuts DNA wherever the researcher desires, allowing for precise addition, subtraction, or modification of genes (Pennisi 2013). This exciting technology is still in its infancy, but should substantially aid in the speed and accuracy of producing future innovative genetically modified mouse lines.

Another point that must be considered in rodent genetic research is the impact of genetic background and environment on memory studies. Studies using common mouse strains, such C57BL/6J, CBA/J, DBA/2J, 129/SvJ, and BALB/cByJ, show differences in both LTP and performance on various spatial and nonspatial hippocampus-dependent memory tasks (Wehner and Silva 1996; Nguyen et al. 2000). The environment also plays a large role on the interpretation of results. Crabbe and colleagues tested eight commonly used mouse strains on several different behaviors in three different lab- oratories. Despite keeping all other variables as consistent as possible, including the age of the mice and time of day of testing, the researchers found marked differences in behavioral performance between laboratories (Crabbe et al. 1999). Additionally, a recent study indicated that the sex of the experimenter may even differentially alter stress levels in rodents (Sorge et al. 2014). Studies such as these reveal the careful contemplation that must be taken before designing experiments involving mouse behavior.

Finally, an important step in the interpretation of genetic research is the ability to manipulate complete behavioral circuits as opposed to individual genes. Only then can the impact of corticohippocampal circuitry on complex learning and memory behaviors be more comprehensively addressed. The human brain is amazingly complex, consisting of billons of neurons with countless more synaptic connections. Probing one gene, one cell type, or one brain 
region only scratches the surface of the mechanisms underlying behavior. Although the task to study complete behavioral circuits is an arduous one, strategically combining many of the techniques discussed in this review may be the best current approach to begin to tackle this question. However, new genetic techniques are also needed. Exciting new circuit-based approaches are constantly being developed and applied to the field of learning and memory (see Brown et al. 2015; Mayford 2015; Schnitzer 2015). Only 25 years have passed since the development of the first knockout mouse in 1989. Surely the next 25 years will bring about a vastly improved array of new genetic research toolsperhaps capable of addressing in more complete detail the corticohippocampal circuitry underlying learning and memory.

\section{MOUSE DATABASES}

Mouse Lines Available

Mutant Mouse Regional Resource Centers (MMRRC): www.mmrrc.org Jackson Laboratory: www.jaxmice.jax.org International Mouse Strain Resource (IMSR): www.findmice.org

\section{Mouse Genome Browsers}

UCSC Genome Browser: www.genome.ucsc.edu Jackson Laboratory: www.informatics.jax.org

\section{ACKNOWLEDGMENTS}

We thank Sarah Ferri, Shane Poplawski, and Rolf Hansen III for comments on a previous version of this manuscript.

\section{REFERENCES}

${ }^{*}$ Reference is also in this collection.

Abel T, Nguyen PV, Barad M, Deuel TA, Kandel ER, Bourtchouladze R. 1997. Genetic demonstration of a role for PKA in the late phase of LTP and in hippocampus-based long-term memory. Cell 88: 615-626.

Alarcón JM, Malleret G, Touzani K, Vronskaya S, Ishii S, Kandel ER, Barco A. 2004. Chromatin acetylation, memory, and LTP are impaired in $\mathrm{CBP}^{+/-}$mice: A model for the cognitive deficit in Rubinstein-Taybi syndrome and its amelioration. Neuron 42: 947-959.

Alexander GM, Rogan SC, Abbas AI, Armbruster BN, Pei Y, Allen JA, Nonneman RJ, Hatmann J, Moy SS, Nicolelis MA, et al. 2009. Remote control of neuronal activity in transgenic mice expressing evolved G protein-coupled receptors. Neuron 63: 27-39.

Altman J, Das GD. 1965. Autoradiographic and histological evidence of postnatal hippocampal neurogenesis in rats. J Comp Neurol 124: 319-335.

Apergis-Schoute J, Pinto A, Paré D. 2007. Muscarinic control of long-range GABAergic inhibition within the rhinal cortices. J Neurosci 27: 4061-4071.

Araque A, Parpura V, Sanzgiri RP, Haydon PG. 1998. Glutamate-dependent astrocyte modulation of synaptic transmission between cultured hippocampal neurons. Eur J Neurosci 10: 2129-2142.

Balthasar N, Coppari R, McMinn J, Liu SM, Lee CE, Tang V, Kenny CD, McGovern RA, Chua SC, Elmquist JK, et al. 2004. Leptin receptor signaling in POMC neurons is required for normal body weight homeostasis. Neuron 42: 983-991.

Bannerman DM, Bus T, Taylor A, Sanderson DJ, Schwarz I, Jensen V, Hvalby O, Rawlins JN, Seeburg PH, Sprengel R. 2012. Dissecting spatial knowledge from spatial choice by hippocampal NMDA receptor deletion. Nat Neurosci 15: 1153-1159.

Berry MD. 2004. Mammalian central nervous system trace amines. Pharmacologic amphetamines, physiologic neuromodulators. J Neurochem 90: 257-271.

Blendy JA, Kaestner KH, Schmid W, Gass P, Schutz G. 1996 Targeting of the CREB gene leads to up-regulation of a novel CREB mRNA isoform. EMBO J 15: 1098-1106.

Bliss TV, Collingridge GL. 1993. A synaptic model of memory: Long-term potentiation in the hippocampus. Nature 361: 31-39.

Bourtchuladze R, Frenguelli B, Blendy J, Cioffi D, Schutz G, Silva AJ. 1994. Deficient long-term memory in mice with a targeted mutation of the cAMP-responsive elementbinding protein. Cell 79: 59-68

Boyden ES, Zhang F, Bamberg E, Nagel G, Deisseroth K. 2005. Millisecond-timescale, genetically targeted optica control of neural activity. Nat Neurosci 8: 1263-1268.

Bradley A, Evans M, Kaufman MH, Robertson E. 1984. Formation of germ-line chimaeras from embryo-derived teratocarcinoma cell lines. Nature 309: 255-256.

Brandon EP, Zhuo M, Huang Y-Y, Ming Q, Gerhold KA, Burton KA, Kandel ER, McKnight GS, Idzerda RL. 1995. Hippocampal long-term depression and depotentiation are defective in mice carrying a targeted disruption of the gene encoding the RI $\beta$ subunit of cAMP-dependent protein kinase. Proc Natl Acad Sci 92: 8852-8855.

Brenner M, Kisseberth WC, Su Y, Besnard F, Messing A. 1994. GFAP promoter directs astrocyte-specific expression in transgenic mice. J Neurosci 14: 1030-1037.

* Brown TI, Staresina BP, Wagner AD. 2015. Noninvasive functional and anatomical imaging of the human medial temporal lobe. Cold Spring Harb Perspect Biol 7: a021840.

Bukalo O, Fentrop N, Lee AY, Salmen B, Law JW, Wotjak CT, Schweizer M, Dityatev A, Schachner M. 2004. Condition- 
al ablation of the neural cell adhesion molecule reduces precision of spatial learning, long-term potentiation, and depression in the CA1 subfield of mouse hippocampus. J Neurosci 24: 1565-1577.

Cao X, Wang H, Mei B, An S, Yin L, Wang LP, Tsien JZ. 2008. Inducible and selective erasure of memories in the mouse brain via chemical-genetic manipulation. Neuron 60: $353-366$.

Cole AJ, Saffen DW, Baraban JM, Worley PF. 1989. Rapid increase of an immediate early gene messenger RNA in hippocampal neurons by synaptic NMDA receptor activation. Nature 340: 474-476.

Cornell-Bell AH, Finkbeiner SM, Cooper MS, Smith SJ. 1990. Glutamate induces calcium waves in cultured astrocytes: Long-range glial signaling. Science 247: 470473.

Crabbe JC, Wahlsten D, Dudek BC. 1999. Genetics of mouse behavior: Interactions with laboratory environment. Science 284: 1670-1672.

Cunha C, Angelucci A, D’Antoni A, Dobrossy MD, Dunnett SB, Berardi N, Brambilla R. 2009. Brain-derived neurotrophic factor (BDNF) overexpression in the forebrain results in learning and memory impairments. Neurobio Dis 33: 358-368.

Doetschman T, Gregg RG, Maeda N, Hooper ML, Melton DW, Thompson S, Smithies O. 1987. Targeted correction of a mutant HPRT gene in mouse embryonic stem cells. Nature 330: 576-578.

Dudai Y, Jan Y-N, Byers D, Quinn W, Benzer S. 1976. dunce, a mutant of Drosophila melanogaster deficient in learning. Proc Natl Acad Sci 73: 1684-88.

Eriksson PS, Perfilieva E, Björk-Eriksson T, Alborn AM, Nordborg C, Peterson DA, Gage FH. 1998. Neurogenesis in the adult human hippocampus. Nat Med 4: 13131317.

Evans MJ, Kaufman MH. 1981. Establishment in culture of pluripotential cells from mouse embryos. Nature 292: 154-156.

Flavell SW, Cowan CW, Kim TK, Greer PL, Lin Y, Paradis S, Griffith EC, Hu LS, Chen C, Greenberg ME. 2006. Activity-dependent regulation of MEF2 transcription factors suppresses excitatory synapse number. Science 311: 1008-1012.

Florian CD, Vecsey CG, Halassa MM, Haydon PG, Abel T. 2011. Astrocyte-derived adenosine and Al receptor activity contribute to sleep loss-induced deficits in hippocampal synaptic plasticity and memory in mice. J Neurosci 31: 6956-6962.

Forrest D, Yuzaki M, Soares HD, Ng L, Luk DC, Sheng M, Stewart CL, Morgan JI, Connor JA, Curran T. 1994. Targeted disruption of NMDA receptor 1 gene abolishes NMDA response and results in neonatal death. Neuron 13: $325-338$.

Forss-Petter S, Danielson PE, Catsicas S, Battenberg E, Price J, Nerenberg M, Sutcliffe JG. 1990. Transgenic mice expressing $\beta$-galactosidase in mature neurons under neuron-specific enolase promoter control. Neuron 5: 187197.

Furtak SC, Wei SM, Agster KL, Burwell RD. 2007. Functional neuroanatomy of the parahippocampal region in the rat: The perirhinal and postrhinal cortices. Hippocampus 17: 709-722.
Garner AR, Rowland DC, Hwang SY, Baumgaertel K, Roth BL, Kentros C, Mayford M. 2012. Generation of a synthetic memory trace. Science 335: 1513-1516.

Gass P, Wolfer DP, Balschun D, Rudolph D, Frey U, Lipp HP, Schutz G. 1998. Deficits in memory tasks of mice with CREB mutations depend on gene dosage. Learn Mem 5: 274-288.

Gerfen CR, Engber TM, Mahan LC, Susel Z, Chase TN, Monsma FJ, Sibley DR. 1990. D1 and D2 dopamine receptor regulated gene expression of striatonigral and striatopallidal neurons. Science 250: 1429-1432.

Goshen I, Brodsky M, Prakash R, Wallace J, Gradinaru V, Ramakrishnan C, Deisseroth K. 2011. Dynamics of retrieval strategies for remote memories. Cell 147: 678689.

Gossen M, Bujard H. 1992. Tight control of gene expression in mammalian cells by tetracycline-responsive promoters. Proc Natl Acad Sci 89: 5547-5551.

Guan JS, Haggarty SJ, Giacometti E, Dannenberg JH, Joseph $\mathrm{N}$, Gao J, Nieland T, Zhou Y, Wang X, Mazitschek R, et al. 2009. HDAC2 negatively regulates memory formation and synaptic plasticity. Nature 459: 55-60.

Guzowski JF, Setlow B, Wagner EK, McGaugh JL. 2001. Experience-dependent gene expression in the rat hippocampus after spatial learning: A comparison of the immediate-early genes Arc, c-fos, and zif268. J Neurosci 21: 5089-5098.

Halassa MM, Florian C, Fellin T, Munoz JR, Lee SY, Abel T, Haydon PG, Frank MG. 2009. Astrocytic modulation of sleep homeostasis and cognitive consequences of sleep loss. Neuron 61: 213-219.

Hall J, Thomas KL, Everitt BJ. 2001. Cellular imaging of zif268 expression in the hippocampus and amygdala during contextual and cued fear memory retrieval: Selective activation of hippocampal CA1 neurons during the recall of contextual memories. J Neurosci 21: 2186-2193.

Havekes R, Abel T. 2009. Genetic dissection of neural circuits and behavior in Mus musculus. Adv Genet 65: 1-38.

Havekes R, Bruinenberg VM, Tudor JC, Ferri SL, Baumann A, Meerlo P, Abel T. 2014. Transiently increasing cAMP levels selectively in hippocampal excitatory neurons during sleep deprivation prevents memory deficits caused by sleep loss. J Neurosci 34: 15715-15721.

Herskowitz I. 1987. Functional inactivation of genes by dominant negative mutations. Nature 329: 219-222.

Higashi AY, Ikawa T, Muramatsu M, Economides AN, Niwa A, Okuda T, Murphy AJ, Rojas J, Heike T, Nakahata T, et al. 2009. Direct hematological toxicity and illegitimate chromosomal recombination caused by the systemic activation of CreER ${ }^{\mathrm{T} 2}$. J Immunol 182: 5633-5640.

Hoeffer CA, Tang W, Wong H, Santillan A, Patterson RJ, Martinez LA, Tejada-Simon MV, Paylor R, Hamilton SL, Klann E. 2008. Removal of FKBP12 enhances mTOR-Raptor interactions, LTP, memory, and perseverative/repetitive behavior. Neuron 60: 832-845.

Imayoshi I, Sakamoto M, Ohtsuka T, Takao K, Miyakawa T, Yamaguchi M, Mori K, Ikeda T, Itohara S, Kageyama R. 2008. Roles of continuous neurogenesis in the structural and functional integrity of the adult forebrain. $\mathrm{Nat} \mathrm{Neu-}$ rosci 11: 1153-1161. 
Isiegas C, Park A, Kandel ER, Abel T, Lattal KM. 2006. Transgenic inhibition of neuronal protein kinase A activity facilitates fear extinction. J Neurosci 26: 12700-12707.

Isiegas C, McDonough C, Huang T, Havekes R, Fabian S, Wu LJ, Xu H, Zhao MG, Kim JI, Lee YS, et al. 2008. A novel conditional genetic system reveals that increasing neuronal cAMP enhances memory and retrieval. J Neurosci $\mathbf{2 8}$ $6220-6230$.

Jones MW, Errington ML, French PJ, Fine A, Bliss TVP, Garel S, Charnay P, Bozon B, Laroche S, Davis S. 2001. A requirement for the immediate early gene Zif268 in the expression of late LTP and long-term memories. $\mathrm{Nat} \mathrm{Neu}$ rosci 4: $289-296$

Kim JJ, Fanselow MS. 1992. Modality-specific retrograde amnesia of fear. Science 256: 675-677.

Kitamura T, Pignatelli M, Suh J, Kohara K, Yoshiki A, Abe K, Tonegawa S. 2014. Island cells control temporal association memory. Science 343: 896-901.

Kohara K, Pignatelli M, Rivest AJ, Jung HY, Kitamura T, Suh J, Frank D, Kajikawa K, Mise N, Obata Y, et al. 2014. Cell type-specific genetic and optogenetic tools reveal hippocampal CA2 circuits. Nat Neurosci 17: 269-279.

Korzus E, Rosenfeld MG, Mayford M. 2004. CBP histone acetyltransferase activity is a critical component of memory consolidation. Neuron 42: 961-972.

Leach PT, Poplawski SG, Kenney JW, Hoffman B, Liebermann DA, Abel T, Gould TJ. 2012. Gadd45b knockout mice exhibit selective deficits in hippocampus-dependent long-term memory. Learn Mem 19: 319-324.

Limbäck-Stokin K, Korzus E, Nagaoka-Yasuda R, Mayford M. 2004. Nuclear calcium/calmodulin regulates memory consolidation. J Neurosci 24: 10858-10867.

Livingstone MS, Sziber PP, Quinn WG. 1984. Loss of calcium/calmodulin responsiveness in adenylate cyclase of rutabaga, a Drosophila learning mutant. Cell 137: $205-$ 215.

Lovett-Barron M, Kaifosh P, Kheirbek MA, Danielson N, Zaremba JD, Reardon TR, Turi GF, Zemelman Hen R, Losonczy A. 2014. Dendritic inhibition in the hippocampus supports fear learning. Science 343: 857-863.

Ma D, Jang M-H, Guo JU, Kitabatake Y, Chang M-L, PowAnpongkul N, Flavell RA, Lu B, Ming G-L, Song H. 2009. Neuronal activity-induced Gadd45b promotes epigenetic DNA demethylation and adult neurogenesis. Science 323: 1074-1077.

Mansour SL, Thomas KR, Capecchi MR. 1988. Disruption of the proto-oncogene int-2 in mouse embryo-derived stem cells: A general strategy for targeting mutations to non-selectable genes. Nature 336: 348-352.

Maren S, Aharonov G, Fanselow MS. 1997. Neurotoxic lesions of the dorsal hippocampus and Pavlovian fear conditioning in rats. Behav Brain Res 88: 261-274.

* Mayford MR. 2015. Genetics of active circuits. Cold Spring Harb Perspect Biol doi: 10.1101/cshperspect.a021832.

Mayford M, Baranes D, Podsypanina K, Kandel ER. 1996a. The $3^{\prime}$-untranslated region of CaMKII $\alpha$ is a cis-acting signal for the localization and translation of mRNA in dendrites. Proc Natl Acad Sci 93: 13250-13255.

Mayford M, Bach ME, Huang YY, Wang L, Hawkins RD, Kandel ER. 1996b. Control of memory formation through regulated expression of a CaMKII transgene. Science 274: 1678-1683.

McHugh TJ, Blum KI, Tsien JZ, Tonegawa S, Wilson MA. 1996. Impaired hippocampal representation of space in CA1-specific NMDAR1 knockout mice. Cell 87: 13391349.

McHugh TJ, Jones MW, Quinn JJ, Balthasar N, Coppari R, Elmquist JK, Lowell BB, Fanselow MS, Wilson MA, Tonegawa S. 2007. Dentate gyrus NMDA receptors mediate rapid pattern separation in the hippocampal network Science 317: 94-99.

Metzger D, Clifford J, Chiba H, Chambon P. 1995. Conditional site-specific recombination in mammalian cells using a ligand-dependent chimeric Cre recombinase. Proc Natl Acad Sci 92: 6991-6995.

* Moser M-B, Rowland DC, Moser EI. 2015. Place cells, grid cells, and memory. Cold Spring Harb Perspect Biol 7: a021808.

Nagel G, Szellas T, Huhn W, Kateriya S, Adeishvili N, Berthold P, Ollig D, Hegemann P, Bamberg E. 2003. Channelrhodopsin-2, a directly light-gated cation-selective membrane channel. Proc Natl Acad Sci 100: 13940 13945.

Nakashiba T, Young JZ, McHugh TJ, Buhl DL, Tonegawa S. 2008. Transgenic inhibition of synaptic transmission reveals role of CA3 output in hippocampal learning. Science 319: $1260-1264$.

Nakashiba T, Buhl DL, McHugh TJ, Tonegawa S. 2009. Hippocampal CA3 output is crucial for ripple-associated reactivation and consolidation of memory. Neuron 62: 781-787.

Nakashiba T, Cushman JD, Pelkey KA, Renaudineau S, Buhl DL, McHugh TJ, Rodriguez Barrera V, Chittajallu R, Iwamoto KS, McBain CJ, et al. 2012. Young dentate granule cells mediate pattern separation, whereas old granule cells facilitate pattern completion. Cell 149: 188-201.

Nakazawa K, Quirk MC, Chitwood RA, Watanabe M, Yeckel MF, Sun LD, Kato A, Carr CA, Johnston D, Wilson MA, et al. 2002. Requirement for hippocampal CA3 NMDA receptors in associative memory recall. Science 297: 211-218.

Nakazawa K, Sun LD, Quirk MC, Rondi-Reig L, Wilson MA, Tonegawa S. 2003. Hippocampal CA3 NMDA receptors are crucial for memory acquisition of one-time experience. Neuron 38: 305-315.

Nguyen PV, Abel T, Kandel ER, Bourtchouladze R. 2000. Strain-dependent differences in LTP and hippocampusdependent memory in inbred mice. Learn Mem 7: $170-$ 179.

Oberdick J, Smeyne RJ, Mann JR, Zackson S, Morgan JI. 1990. A promoter that drives transgene expression in cerebellar Purkinje and retinal bipolar neurons. Science 248: 223-226.

O'Keefe J, Dostrovsky J. 1971. The hippocampus as a spatial map. Preliminary evidence from unit activity in the freely-moving rat. Brain Res 34: 171-175.

Oliveira AM, Wood MA, McDonough CB, Abel T. 2007. Transgenic mice expressing an inhibitory truncated form of p300 exhibit long-term memory deficits. Learn Mem 14: 564-572. 
Oliveira AM, Estévez MA, Hawk JD, Grimes S, Brindle PK, Abel T. 2011. Subregion-specific p300 conditional knock-out mice exhibit long-term memory impairments. Learn Mem 18: 161-169.

Oltval ZN, Milliman CL, Korsmeyer SJ. 1993. Bcl-2 heterodimerizes in vivo with a conserved homolog, Bax, that accelerates programed cell death. Cell 74: 609-619.

Palmiter RD, Brinster RL, Hammer RE, Trumbauer ME Rosenfeld MG, Birnberg NC, Evans RM. 1982. Dramatic growth of mice that develop from eggs microinjected with metallothionein-growth hormone fusion genes. $\mathrm{Na}$ ture 300: 611-615.

Pascual O, Casper KB, Kubera C, Zhang J, Revilla-Sanchez R, Sul JY, Takano H, Moss SJ, McCarthy K, Haydon PG. 2005. Astrocytic purinergic signaling coordinates synaptic networks. Science 310: 113-116.

Pennisi E. 2013. The CRISPR craze. Science 341: 833-836.

Qi M, Zhuo M, Skålheggm BS, Brandon EP, Kandel ER, McKnight GS, Idzerda RL. 1996. Impaired hippocampal plasticity in mice lacking the $C \beta_{1}$ catalytic subunit of cAMP-dependent protein kinase. Proc Natl Acad Sci 93: 1571-1576.

Ramirez S, Liu X, Lin PA, Suh J, Pignatelli M, Redondo RL, Ryan TJ, Tonegawa S. 2013. Creating a false memory in the hippocampus. Science 341: 387-391.

Sahay A, Scobie KN, Hill AS, O'Carroll CM, Kheirbek MA, Burghardt NS, Fenton AA, Dranovsky A, Hen R. 2011. Increasing adult hippocampal neurogenesis is sufficient to improve pattern separation. Nature 472: 466-470.

Sando R III, Baumgaertel K, Pieraut S, Torabi-Rander N, Wandless TJ, Mayford M, Maximov A. 2013. Inducible control of gene expression with destabilized Cre. Nat Methods 10: 1085-1088.

Sauer B, Henderson N. 1988. Site-specific DNA recombination in mammalian cells by the Cre recombinase of bacteriophage P1. Proc Natl Acad 85: 5166-5170.

* Schnitzer M. 2015. New methods involved in studying large populations of neurons involved in memory storage. Cold Spring Harb Perspect Biol doi: 10.1101/cshper spect.a021824.

Shimizu E, Tang YP, Rampon C, Tsien JZ. 2000. NMDA receptor-dependent synaptic reinforcement as a crucial process for memory consolidation. Science 290: 11701174.

Silva AJ, Stevens CF, Tonegawa S, Wang Y. 1992a. Deficient hippocampal long-term potentiation in $\alpha$-calcium-calmodulin kinase II mutant mice. Science 257: 201-206.

Silva AJ, Paylor R, Wehner JM, Tonegawa S. 1992b. Impaired spatial learning in $\alpha$-calcium-calmodulin kinase II mutant mice. Science 257: 206-211.

Smithies O, Gregg RG, Boggs SS, Koralewski MA, Kucherlapati RS. 1985. Insertion of DNA sequences into the human chromosomal $\beta$-globin locus by homologous recombination. Nature 317: 230-234.

Sorge RE, Martin LJ, Isbester KA, Sotocinal SG, Rosen S, Tuttle AH, Wieskopf JS, Acland EL, Dokova A, Kadoura B, et al. 2014. Olfactory exposure to males, including men, causes stress and related analgesia in rodents. Nat Methods 11: 629-632.
Steele RJ, Morris RGM. 1999. Delay-dependent impairment of a matching-to-place task with chronic and intrahippocampal infusion of the NMDA-antagonist D-AP5. Hippocampus 9: 118-136.

Strader CD, Gaffney T, Sugg EE, Candelore MR, Keys R, Patchett AA, Dixon RA. 1991. Allele-specific activation of genetically engineered receptors. J Biol Chem 266: 5-8.

Struthers RS, Vale WW, Arias C, Sawchenko PE, Montminy MR. 1991. Somatotroph hypoplasia and dwarfism in transgenic mice expressing a non-phosphorylatable CREB mutant. Nature 350: 622-624.

Su SC, Rudenko A, Cho S, Tsai LH. 2013. Forebrain-specific deletion of Cdk5 in pyramidal neurons results in manialike behavior and cognitive impairment. Neurobiol Learn Mem 105: 54-62.

Sugiura H, Yamauchi T. 1992. Developmental changes in the levels of $\mathrm{Ca}^{2+} /$ calmodulin-dependent protein kinase II $\alpha$ and $\beta$ proteins in soluble and particulate fractions of the rat brain. Brain Res 593: 97-104.

Suh J, Rivest AJ, Nakashiba T, Tominaga T, Tonegawa $S$. 2011. Entorhinal cortex layer III input to the hippocampus is crucial for temporal association memory. Science 334: $1415-1420$.

Takahashi T, Guron C, Shetty S, Matsui H, Raghow R. 1997. A minimal murine $M s x-1$ gene promoter. J Biol Chem 272: $22667-22678$.

Takahashi JS, Shimomura K, Kumar V. 2008. Searching for genes underlying behavior: Lessons from circadian rhythms. Science 322: 909-912.

Thomas KR, Capecchi MR. 1987. Site-directed mutagenesis by gene targeting in mouse embryo-derived stem cells. Cell 51: 503-512.

Tsien JZ, Chen DF, Gerber D, Tom C, Mercer EH, Anderson DJ, Mayford M, Kandel ER, Tonegawa S. 1996a. Subregion- and cell-type-restricted gene knockout in mouse brain. Cell 87: 1317-1326.

Tsien JZ, Huerta PT, Tonegawa S. 1996b. The essential role of hippocampal CA1 NMDA receptor-dependent synaptic plasticity in spatial memory. Cell 87: $1327-$ 1338.

Vetere G, Restivo L, Cole CJ, Ross PJ, Ammassari-Teule M, Josselyn SA, Frankland PW. 2011. Spine growth in the anterior cingulate cortex is necessary for the consolidation of contextual fear memory. Proc Natl Acad Sci 108: 8456-8460.

Vo N, Goodman RH. 2001. CREB-binding protein and p300 in transcriptional regulation. J Biol Chem 276: 1350513508 .

Warburton EC, Glover CP, Massey PV, Wan H, Johnson B, Bienemann A, Deuschle U, Kew JN, Aggleton JP, Bashir $\mathrm{ZI}$, et al. 2005. cAMP responsive element-binding protein phosphorylation is necessary for perirhinal long-term potentiation and recognition memory. $J$ Neurosci 25: 6296-6303.

Wehner JM, Silva A. 1996. Importance of strain differences in evaluations of learning and memory processes in null mutants. Ment Retard Dev Disabil Res Rev 2: $243-248$.

Wiltgen BJ, Royle GA, Gray EE, Abdipranoto A, Thangthaeng N, Jacobs N, Saab F, Tonegawa S, Heinemann SF, O’Dell TJ, et al. 2010. A role for calcium-permeable 


\section{C.C. Angelakos and T. Abel}

AMPA receptors in synaptic plasticity and learning. PLoS ONE 5: e12818.

Wisden W, Seeburg PH. 1993. A complex mosaic of highaffinity kainate receptors in rat brain. J Neurosci 13: 3582-3598.

Wood MA, Kaplan MP, Park A, Blanchard EJ, Oliveira AM, Lombardi TL, Abel T. 2005. Transgenic mice expressing a truncated form of CREB-binding protein (CBP) exhibit deficits in hippocampal synaptic plasticity and memory storage. Learn Mem 12: 111-119.

Wood MA, Attner MA, Oliveira AM, Brindle PK, Abel T. 2006. A transcription factor-binding domain of the coactivator CBP is essential for long-term memory and the expression of specific target genes. Learn Mem 13: 609-617.

Xu B, Gottschalk W, Chow A, Wilson RI, Schnell E, Zang K, Wang D, Nicoll A, Lu B, Reichardt LF. 2000. The role of brain-derived neurotrophic factor receptors in the mature hippocampus: Modulation of long-term potentiation through a presynaptic mechanism involving TrkB. J Neurosci 20: 6888-6897.

Yoneshima H, Yamasaki S, Voelker CC, Molnar Z, Christophe E, Audinat E, Takemoto M, Nishiwaki M, Tsuji S, Fujita I, et al. 2006. Er81 is expressed in a subpopulation of layer 5 neurons in rodent and primate neocortices. Neuroscience 137: 401-412. 


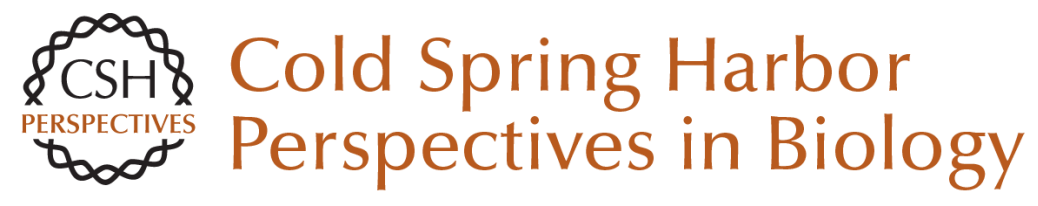

\section{Molecular Genetic Strategies in the Study of Corticohippocampal Circuits}

Christopher C. Angelakos and Ted Abel

Cold Spring Harb Perspect Biol 2015; doi: 10.1101/cshperspect.a021725

Subject Collection Learning and Memory

Large-Scale Fluorescence Calcium-Imaging

Methods for Studies of Long-Term Memory in

Behaving Mammals

Pablo Jercog, Thomas Rogerson and Mark J. Schnitzer

Exploring Memory Representations with

Activity-Based Genetics

Mark Mayford and Leon Reijmers

The Origins and Organization of Vertebrate

Pavlovian Conditioning

Michael S. Fanselow and Kate M. Wassum

The Corticohippocampal Circuit, Synaptic

Plasticity, and Memory

Jayeeta Basu and Steven A. Siegelbaum

Motor Learning and the Cerebellum

Chris I. De Zeeuw and Michiel M. Ten Brinke

The Striatum: Where Skills and Habits Meet Ann M. Graybiel and Scott T. Grafton

Molecular Genetic Strategies in the Study of

\section{Corticohippocampal Circuits}

Christopher C. Angelakos and Ted Abel

Nonassociative Learning in Invertebrates John H. Byrne and Robert D. Hawkins
The Role of Functional Prion-Like Proteins in the

Persistence of Memory

Kausik Si and Eric R. Kandel

Working Memory: Maintenance, Updating, and the

Realization of Intentions

Lars Nyberg and Johan Eriksson

Memory Retrieval in Mice and Men

Aya Ben-Yakov, Yadin Dudai and Mark R. Mayford

Reconsolidation and the Dynamic Nature of Memory

Karim Nader

Memory Consolidation

Larry R. Squire, Lisa Genzel, John T. Wixted, et al.

Structural Components of Synaptic Plasticity and

Memory Consolidation

Craig H. Bailey, Eric R. Kandel and Kristen M. Harris

Associative Learning in Invertebrates

Robert D. Hawkins and John H. Byrne

The Regulation of Transcription in Memory

Consolidation

Cristina M. Alberini and Eric R. Kandel

For additional articles in this collection, see http://cshperspectives.cshlp.org/cgi/collection/

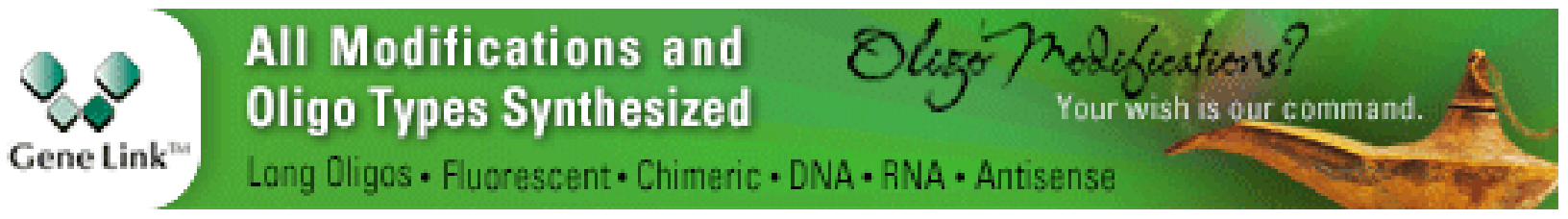

Copyright @ 2015 Cold Spring Harbor Laboratory Press; all rights reserved 